\title{
AVIATOR: An open international registry to evaluate medical and surgical outcomes of aortic valve insufficiency and ascending aorta aneurysm
}

Frederiek de Heer, MSc, ${ }^{a}$ Jolanda Kluin, MD, PhD, ${ }^{a}$ Gebrine Elkhoury, MD, $\mathrm{PhD},{ }^{\mathrm{b}}$

Guillaume Jondeau, MD, PhD ${ }^{\mathrm{c}}$ Maurice Enriquez-Sarano, MD, ${ }^{\mathrm{d}}$ Hans-Joachim Schäfers, MD, PhD, Johanna J. M. Takkenberg, MD, PhD, ${ }^{f}$ and Emmanuel Lansac, MD, $\mathrm{PhD},{ }^{g}$ on behalf of the Aortic Valve Repair Research Network Investigators

\section{ABSTRACT}

Objectives: Current national registries are lacking detailed pathology-driven analysis and long-term patients outcomes. The Heart Valve Society (HVS) aortic valve (AV) repair research network started the Aortic Valve Insufficiency and ascending aorta Aneurysm InternATiOnal Registry (AVIATOR) to evaluate long-term patient outcomes of $\mathrm{AV}$ repair and replacement. The purpose of the current report is to describe the AVIATOR initiative and report in a descriptive manner the patients included.

Methods: The AV repair research network includes surgeons, cardiologists, and scientists and established an online database compliant with the guidelines for reporting valve-related events. Prospective inclusion started from January 2013. Adult patients (18 years or older) who were operated on between 1995 and 2017 with complete procedural specification of the type of repair/replacement were selected for descriptive analysis.

Results: Currently 58 centers from 17 countries include 4896 patients with $89 \%$ $\mathrm{AV}$ repair $(\mathrm{n}=4379)$ versus $11 \% \mathrm{AV}$ replacement $(\mathrm{n}=517)$. $\mathrm{AV}$ repair was either isolated $(28 \%)$, or associated with tubular/partial root replacement $(22 \%)$ or valve-sparing root replacement $(49 \%)$ with an in-hospital mortality of $0.5 \%$, $1.7 \%$, and $1.2 \%$, respectively. AV replacement was either isolated (24\%), associated with tubular/partial root replacement $(17 \%)$ or root replacement $(59 \%)$ with an in-hospital mortality of $1 \%, 2.6 \%$, and $2.0 \%$, respectively.

Conclusions: The multicenter surgical AVIATOR registry, by applying uniform definitions, should provide a solid evidence base to evaluate the place of repair versus replacement on the basis of long-term patient outcomes. Obtaining data completeness and adequate representation of all surgery types remain challenging. Toward the near future AVIATOR-medical will start to study natural history, as will AVIATOR-kids, with a focus on pediatric disease. (J Thorac Cardiovasc Surg 2019;157:2202-11)

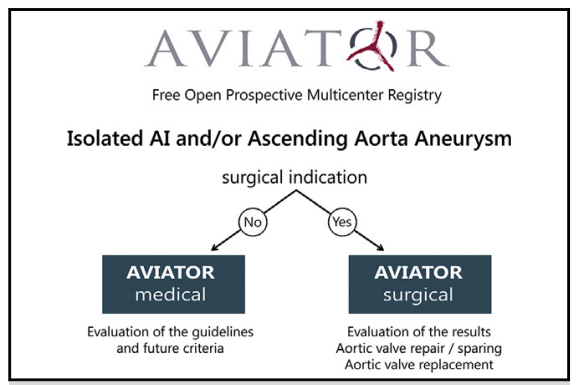

AVIATOR includes the whole disease trajectory of patients with Al and/or AscAo Aneurysm.

\section{Central Message}

The AVIATOR currently contains data on 4896 patients with $89 \%$ aortic valve repair-isolated $(28 \%)$, with tubular replacement $(22 \%)$ or valve-sparing root replacement $(49 \%)$-and $11 \%$ valve replacement.

\section{Perspective}

The AVIATOR is a unique registry open to any center taking care of patients with ascending aorta aneurysm and/or isolated aortic valve insufficiency. It will address key epidemiology questions, stimulate uniform reporting to evaluate the guidelines for surgical indication, and define the place of aortic valve repair versus replacement on the basis of long-term patient outcomes.

See Commentary on page 2212 .
The prevalence of aortic regurgitation (AR) is difficult to assess because it is well tolerated for a long period before symptoms emerge. ${ }^{1}$ Results from the population-based

\footnotetext{
From the a Department of Cardio-Thoracic Surgery, Academic Medical Center, Amsterdam, The Netherlands; 'bepartment of Cardiovascular and Thoracic Surgery, Cliniques universitaires Saint-Luc, Bruxelles, Belgium; ${ }^{\mathrm{c}}$ Department of Cardiology, Claude Bichat-Claude Bernard Hospital, Paris, France; ${ }^{\mathrm{d} D e p a r t m e n t}$ of Cardiovascular Diseases, Mayo Clinic, Rochester, Minn; ${ }^{\mathrm{e} D e p a r t m e n t}$ of Thoracic and Cardiovascular Surgery, Saarland University Medical Center, Homburg, Germany; ${ }^{\mathrm{f} D e p a r t m e n t}$ of Cardiothoracic Surgery, Erasmus MC Rotterdam, Rotterdam, The Netherlands; and ${ }^{\mathrm{g}}$ Department of Cardiac Surgery, Institut Mutualiste Montsouris, Paris, France.

The Department of Cardio-Thoracic Surgery Academic Medical Center in Amsterdam has provided financial support to cover the first author's salary. Dr E. Lansac received a grant of 100,000 Euros from the Association Chirurgicale Pour Le
}

study in Framingham gave some insight: trace or mild AR was seen in $8.5 \%$ of women and in $13 \%$ of men. ${ }^{2,3}$ Within a hospital-based cohort the Euro Heart Survey

Développement et L'Amélioration des Techniques de Dépistage et de Traitement des Maladies Cardio-vasculaires (France) and Dr J. Kluin invested 30,000 Euros from a research project to initiate the AVIATOR project.

Received for publication June 26, 2018; revisions received Oct 2, 2018; accepted for publication Oct 16, 2018; available ahead of print Dec 12, 2018.

Address for reprints: Frederiek de Heer, MSc, Department of Cardio-Thoracic Surgery, Academic Medical Center, Meibergdreef 9, 1105 AZ Amsterdam,

The Netherlands (E-mail: f.deheer@amc.nl). $0022-5223 / \$ 36.00$

Copyright (C) 2018 by The American Association for Thoracic Surgery https://doi.org/10.1016/j.jtcvs.2018.10.076 


$$
\begin{array}{ll}
\text { Abbreviations and Acronyms } \\
\text { AR } & =\text { aortic regurgitation } \\
\text { AV } & =\text { aortic valve } \\
\text { AVIATOR } & =\text { Aortic Valve repair InternATiOnal } \\
& \text { Registry } \\
\text { CRF } & =\text { Case Report Form } \\
\text { HVS } & =\text { Heart Valve Society } \\
\text { PID } & =\text { patient-identifiable data }
\end{array}
$$

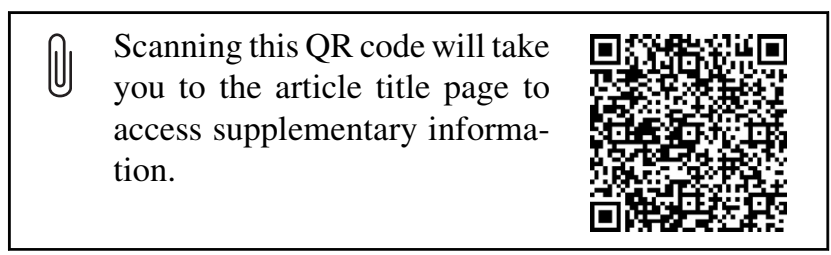

program observed that $10.4 \%$ of the patients with valvular heart disease presented with moderate to severe AR (grade 2-4), of whom $1.7 \%$ underwent aortic valve (AV) repair. ${ }^{4} \mathrm{AV}$ repair started 3 decades ago with valvesparing root replacement using either the reimplantation or remodeling technique. ${ }^{5,6}$ Both techniques have evolved during the years..$^{7-11}$ A recent analysis of the Society of Thoracic Surgeons database reported that $14 \%$ of patients with dystrophic bicuspid or tricuspid AR receive a valve-sparing procedure whereas $80 \%$ receive a composite graft-valve replacement (Bentall procedure). ${ }^{12,13}$ Some patients of the latter group could actually be candidates for repair.

In the current era, relative risk-adjusted mortality of valve-sparing aortic root replacement appears comparable with composite graft replacement in low- and high-risk subgroups. ${ }^{14}$ A recent meta-analysis indicated that AV repair seems a safe and feasible alternative to $\mathrm{AV}$ replacement in selected patients with aortic root aneurysm with or without AR. ${ }^{15,16}$ However, generalization of published results is still difficult because of the heterogeneity or inadequate description of the populations studied. Furthermore, loss to follow-up and incomplete or inadequate reporting of valve-related events makes interpretation of the results difficult. As a result, patients are treated according to guidelines on the basis of 30 -year-old evidence. ${ }^{17,18}$ To achieve a real breakthrough in treatment of AR, collaboration of cardiologists and surgeons is needed because they both treat the same patients at different time points during the course of the disease. Including the complete time span of AR from diagnosis through intervention until death within a longitudinal cohort is essential to investigate key epidemiological questions. Solid evidence-based guidelines cannot do without complete and long-term follow-up.
From here starts the international Aortic Valve repair InternATiOnal Registry (AVIATOR) initiative. The main objectives are to enhance uniform scientific reporting, to optimize multidisciplinary patient care, to assess quality of care, and to update and improve guidelines. The purpose of the current report is to present the registry design and to describe the characteristics of the first enrolled patients.

\section{AVIATOR REGISTRY}

The AVIATOR initiative is a longitudinal observational cohort study enrolling patients with ascending aorta aneurysm and/or AR. The registry contains 2 separate entities: (1) AVIATOR medical registry to evaluate the natural history of nonoperated patients; and (2) AVIATOR surgical registry to evaluate long term outcomes after surgical treatment. Both registries will have an adult and a pediatric counterpart (AVIATOR-kids). The adult surgical database is established and is enrolling patients. AVIATOR medical and AVIATOR kids are in progress and enrollment will follow in the near future.

\section{Inclusion Criteria}

The AVIATOR includes all patients with $\mathrm{AR}$ and/or ascending aorta aneurysms (Figure 1). Adult patients with AR grade $>1$ (mild AR) - inclusive of congenital mixed $\mathrm{AV}$ disease - and/or an aortic diameter $\geq 40 \mathrm{~mm}$ are eligible for the medical registry. Patients who are operated on because of AR (including congenital mixed AV disease) and/or aortic aneurysm (root or tubular ascending aorta) are eligible for the surgical database. Patients operated on for aortic dissection (type A) are eligible as well. Both patients who undergo AV repair including valve-sparing root replacement as well as AV replacement-including composite graft replacement-are eligible. Centers without an AV repair program are encouraged to join the AVIATOR initiative as well. It is important to enroll all consecutive patients within a center, and not only the successful repairs. Operative correction of an aneurysm of the ascending aorta can be either root and/or supracoronary aorta replacement. Excluded are patients with pure aortic stenosis, whereas patients with mixed disease (AR and aortic stenosis) are eligible. This is because of the incidence of mixed disease in the population of individuals with bicuspid and unicuspid valves, who could either have repair or replacement.

\section{Adult Surgical Database}

The following information concerns the adult surgical database, which has been open for patient enrollment since January 2013. Data for patients operated on before that can be uploaded retrospectively, and follow-up will be continued prospectively according to AVIATOR standards. Collected data include: baseline patient characteristics including risk factors for operative mortality (EuroSCORE), procedural information with detailed valve analysis and repair 


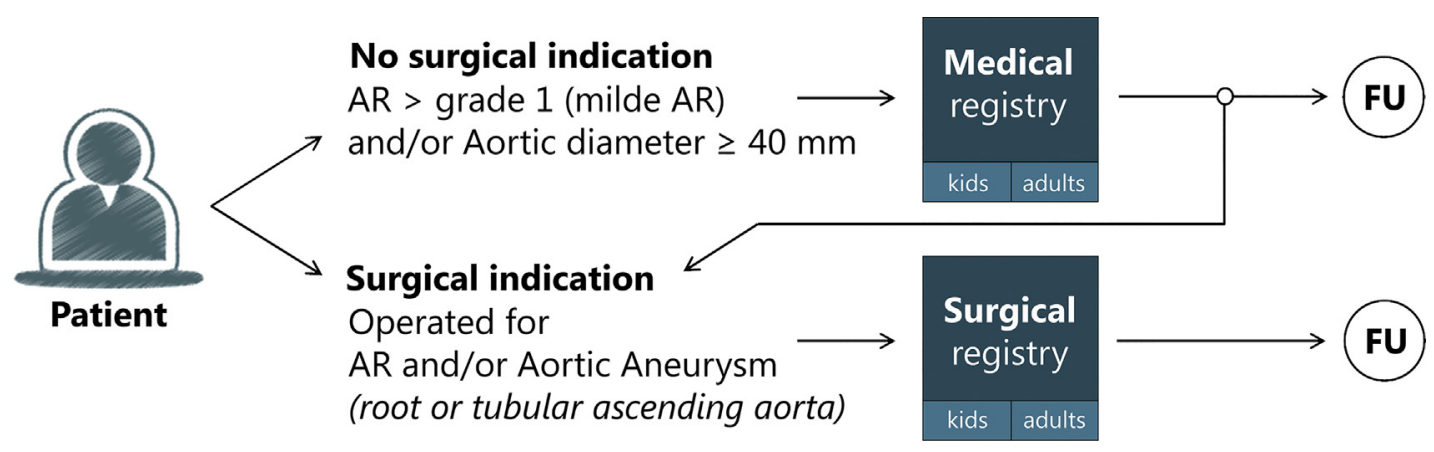

FIGURE 1. Inclusion flow chart. Operations registered in the surgical registry contain: isolated aortic valve (AV) repair/replacement; tubular aorta replacement with or without $\mathrm{AV}$ repair/replacement; partial root replacement with or without $\mathrm{AV}$ repair; valve-sparing root replacement with or without AV repair; root and valve replacement (Bentall). Patients of 18 years or older are eligible in the adult registry. Younger patients can be enrolled in the pediatric counterpart. $A R$, Aortic regurgitation; $F U$, longitudinal follow-up.

procedure, in-hospital outcomes, longitudinal measurement of echo parameters, and valve-related events during at least yearly follow-up according to the guidelines of reporting mortality and morbidity after cardiac valve interventions. ${ }^{19}$ See Figure E1 for the Case Report Form (CRF) containing all variables. There is room for individual center-initiated substudies linked to the core AVIATOR database, for example. a Quality of Life Questionnaire on the basis of the SF36 with extra valve specific questions. This sub-CRF is not mandatory and can be switch on or off. Data entry is possible directly online (patient by patient), but if a center has a good local database, it is possible to use the upload facility.

\section{Clinical Tool}

The AVIATOR registry is designed to be of added value for physicians. Besides data analysis and research it can be used as a clinical tool in daily practice because there is the possibility to generate a "clinical summary" on the patient level. It summarizes all relevant information of that particular patient including echo tables. In addition, the application will allow to filter and select specific subgroups.

\section{DATA ANALYSIS}

\section{Data Ownership and Online Analysis}

The AVIATOR registry is the property of the Heart Valve Society (HVS) that therefore endorses the responsibility of the database, including any multicenter publication originated from it (validated by the scientific committee). Each individual center is the owner of its own submitted data and is responsible for their content. Online extractions can be performed whenever desired. Within the online application, reports and graphs will be developed. Individual center data are not visible for any other center. In a report with summary statistics single-center data will be presented aside with aggregated results of the entire database. Data of centers other than your own are only visible for the central data management group for the purpose of data validation to enhance data quality.

\section{Single-Center Analysis}

Each center can extract its own submitted data for local analysis. Each center is asked to acknowledge the AVIATOR project when single-center results on the basis of this registry are presented or published. For analysis of multicenter data a scientific research proposal is needed. Applications should be submitted to the scientific committee.

\section{Multicenter Analysis}

The scientific committee will review and facilitate initiatives for multicenter analysis. Research proposal submission to the scientific committee is possible twice a year. Submitted proposals will be discussed in detail during the AVIATOR meetings at the Annual Meeting of the HVS and European Association for Cardio-Thoracic Surgery. Proposals are validated when most of the participants during the meeting agree. Each center that can participate in the study will be notified about the accepted proposals and their data will be used automatically (non-opposition procedure). If a center does not agree, the objections should be justified to the scientific committee. The research team will receive an anonymous data set. After data extraction, the team will be given a deadline of 6 months to perform the analysis and write a draft publication that should be presented at the next meeting. When the deadline is exceeded, the topic can be passed on to another group. First and second authorship is for the person who executed the project (ideally young investigators). Last authorship is for the principal investigator of the proposal. Authors in between are those who contributed to the data analysis and included data to the specific research question. Data selection from the AVIATOR database will take into account data completeness. Follow-up completeness will be represented with the $\mathrm{C}^{*}$ ratio: the total observed follow-up years divided by the total potential follow-up years (taking the observed death rate into account). ${ }^{20}$ Each selected center can propose at least 1 author for the studies using its data. Authors will be listed on the basis of their ranking in data completeness 
multiplied by volume (from high to low). The number of authors will depend on journal requirements. Ideally, all participating centers in the research data set will be represented. In case there is limit, centers with the highest "quality data $\times$ volume factor" will come first.

\section{Data Safety}

Data are entered on a Web-based CRF through a secure data entry system. Telemedicine Technologies hosts the database application (CleanWeb) in Boulogne-Billancourt, France. $^{21}$ The data system is set up according to Good Clinical Practice guidelines, is United States Food and Drug Administration-compliant (21 CFR part 11), and meets the criteria of European legislation (EU Directive 2001/20/ EC/Directive 2005/28/EC, Annex 11, cGMP).

\section{Patient-Identifiable Data}

CleanWEB offers the possibility to enter patientidentifiable data (PID) like the last and first name of a patient for practical use in clinic and for future projects enabling collection of patient-reported outcomes measures. Each center can decide if it wishes to enter PID or not, and should inform their institutional review board before enrolling patients. The patient name is subject to special protection regulations. The PID is stored encrypted and is saved on a server separate from the medical parameters. The PID is only visible within the own site. For all other personnel their value will be set to *****. The PID will never be included in extraction files outside its own center.

\section{Organizational Structure}

The Aortic-valve-repair-Research-Network organizes project meetings during the annual meeting of the HVS,
European Association for Cardio-Thoracic Surgery, and AV repair summit, to which all participants are invited. A project update is given as well as outcome of research and/or audit originating from the registry. Besides the members there is a technical support group of the database, a functional support group of the project, and a scientific committee. The scientific committee consists of 7 members, including at least 2 cardiologists, 2 surgeons, and 2 scientists. Members of the committee will serve for 3 years. After their term they have to wait 3 years before they can apply again. The scientific committee reviews research proposals and scientific reports originating from the registry, interacts with other HVS working groups, and advises the HVS board.

\section{Become a Participant}

The AVIATOR network is open to any cardiologist, radiologist, surgeon, and scientist interested in the field. Participation in the AVIATOR registry is free of charge. By signing the participation agreement one automatically becomes a member of the HVS Aortic-valve-repair-Research-Network group and is welcome to visit group meetings. At least 1 surgeon and/or cardiologist per center should be an official member of the HVS. The AVIATOR initiative aims to set up an international research network, in which all participants can be in close contact with their peers, to learn from each other, and to contribute together to improve patient outcomes. Contact: heartvalvesociety.org/AVIATOR or via Email at: AVIATOR@HeartValveSociety.org.

\section{METHODS}

Data were extracted on April 4, 2018. For the analysis all patients between 1995 and 2017 were selected. Patients younger than 18 years or without a registered operation date or procedural specification were excluded

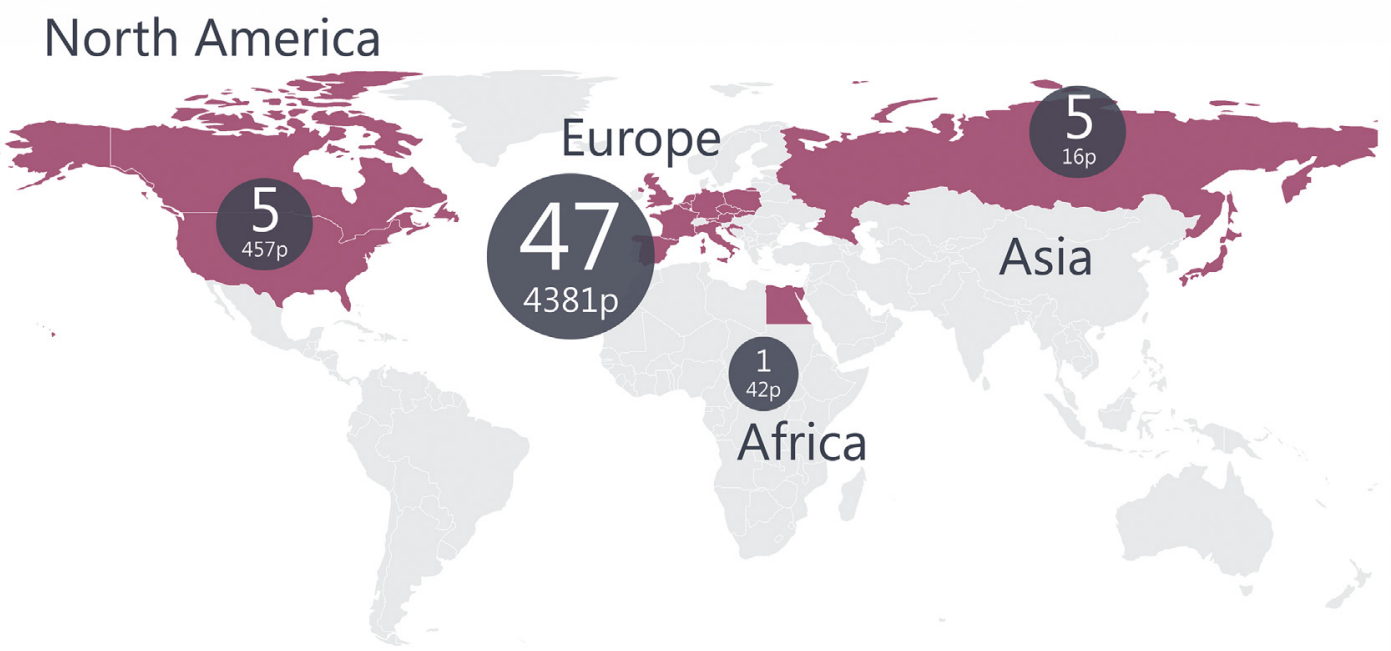

FIGURE 2. Participating cardiothoracic centers, April 2018. Number of participating centers and patients per continent: Africa 1 center with 42 patients $(0.9 \%)$, Asia 5 centers with 16 patients $(0.3 \%)$, Europe 47 centers with 4381 patients $(89.5 \%)$, North America 5 centers with 457 patients $(9.3 \%)$. 
( $\mathrm{n}=288 ; 5.6 \%$ ). This resulted in 4896 patients for analysis. Variables that were added after the initial start of the registry did not reach sufficient data completeness and were therefore not included in the analysis.

\section{RESULTS}

Prospective patient enrolment started in August 2013. Currently 58 cardiothoracic surgery centers participate of which 51 are actively enrolling patients. Fifteen centers enrolled more than 50 patients and were responsible for $91 \%$ of the cohort (Figure 2). Besides prospective data collection, centers uploaded historical data before 2013: approximately half of the patients $(\mathrm{n}=2581 ; 52.7 \%)$ were operated on before 2013. See Figure 3 for the distribution of patients over the years divided by the procedure performed. The AVIATOR registry originated in Europe and especially European centers are enrolling patients at this stage. They are responsible for the inclusion of $4381(89.5 \%)$ patients, followed by North America with $457(9.3 \%)$ patients, Africa with $42(0.9 \%)$ patients, and Asia with $16(0.3 \%)$ patients. Valve repair was the dominant operation with $89 \%$ versus $11 \%$ replacements. The reconstructive surgery consisted of $28 \%$ isolated valve repair, $22 \%$ partial root or tubular aorta replacement with valve repair, and $49 \%$ valve-sparing root replacements. The replaced valves included $24 \%$ isolated valve replacement, $17 \%$ tubular aorta with $\mathrm{AV}$ replacement, $59 \%$ root with valve replacement (Bentall; Table 1). The mean age of the total AVIATOR population is $52( \pm 16)$ years and median age of 53 (interquartile range, 41-65) years. Patients who underwent isolated AV repair were younger $(P<.001)$ than the patients who underwent AV replacement: $48( \pm 16)$ and $56( \pm 16)$ years, respectively. Comparing the 3 main procedural groups between repair and replacement did not show differences in sex. Patients with active endocarditis were more likely to undergo isolated aortic replacement compared with isolated $\mathrm{AV}$ repair $(P<.001)$. Patients who underwent valve-sparing root replacement had a dissection in $7.1 \%$ compared with $5.5 \%$ of the patients who underwent a Bentall procedure. In the latter group completeness was only $65 \%$. Postoperative (in-hospital) outcomes are presented in Table 2. In-hospital mortality was $0.5 \%$ and $1.0 \%$ for isolated $\mathrm{AV}$ repair and replacement, respectively; $1.7 \%$ and $2.6 \%$ for partial root and/or tubular aorta replacement with valve repair and replacement, respectively; and 1.2\% and $2.0 \%$ for valve-sparing root replacement and Bentall procedure, respectively.

\section{DISCUSSION}

The AVIATOR initiative is a unique effort in sharing data worldwide. It has grown exponentially the past 5 years from its birth in 2013 until now. The first descriptive analysis of the AVIATOR population shows the variation of patients and reveals potential biases within the registry (eg, repair vs replacement, high- vs low-volume centers, and European countries vs other regions). This overview is vital to address the current imperfections and to head forward. The registry contains detailed information of the valve anatomy, and the currently applied repair techniques and patch materials used in cusp repair. Although AV repair has reached a degree of maturity there are still ongoing debates: at which cut-off value for aortic annulus diameter is circumferential annuloplasty recommended, and leads symmetrical commissural orientation to better outcomes in bicuspid valve repair, or should AV repair be avoided

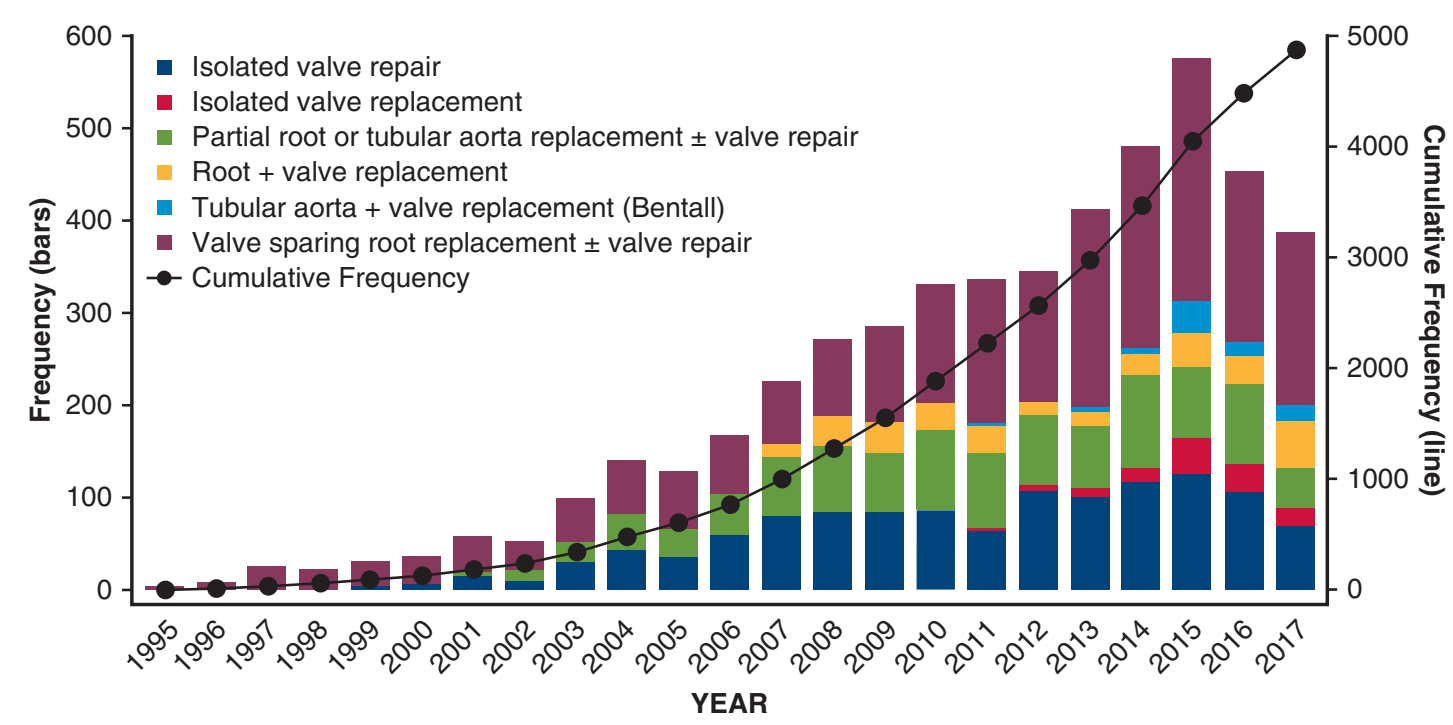

FIGURE 3. Inclusions between 1995 to 2017. Inclusions per year are shown on the left axis. The bar colors reflect the different operative procedures. The right axis shows the cumulative inclusion frequency (black line). 
TABLE 1. Perioperative patient characteristics according to procedure type

\begin{tabular}{|c|c|c|c|c|c|c|c|c|c|c|c|c|c|c|c|}
\hline & \multicolumn{10}{|c|}{$\begin{array}{c}\text { Partial root and/or tubular } \\
\text { aorta replacement } \\
\text { with AV surgery }\end{array}$} & \multicolumn{5}{|c|}{$\begin{array}{c}\text { Root replacement } \\
\text { with AV surgery }\end{array}$} \\
\hline & \multicolumn{2}{|c|}{$\begin{array}{c}\text { Repair } \\
(n=1228)\end{array}$} & \multicolumn{2}{|c|}{$\begin{array}{l}\text { Replacement } \\
(\mathbf{n}=126)\end{array}$} & \multirow{2}{*}{$\begin{array}{c}P \\
\text { value }\end{array}$} & \multicolumn{2}{|c|}{$\begin{array}{c}\text { Repair } \\
(\mathbf{n}=984)\end{array}$} & \multicolumn{2}{|c|}{$\begin{array}{l}\text { Replacement } \\
\quad(\mathbf{n}=86)\end{array}$} & \multirow{2}{*}{$\begin{array}{c}P \\
\text { value }\end{array}$} & \multicolumn{2}{|c|}{$\begin{array}{c}\text { Repair } \\
(n=2168)\end{array}$} & \multicolumn{2}{|c|}{$\begin{array}{l}\text { Replacement } \\
(\mathbf{n}=305)\end{array}$} & \multirow{2}{*}{$\begin{array}{c}P \\
\text { value }\end{array}$} \\
\hline & $\mathbf{n}$ & $\%$ & $\mathbf{n}$ & $\%$ & & $\mathbf{n}$ & $\%$ & $\mathbf{n}$ & $\%$ & & $\mathbf{n}$ & $\%$ & $\mathbf{n}$ & $\%$ & \\
\hline \multicolumn{16}{|l|}{ Age } \\
\hline Total & 1226 & $100 \%$ & 125 & $99 \%$ & & 982 & $100 \%$ & 85 & $99 \%$ & & 2148 & $99 \%$ & 302 & $99 \%$ & \\
\hline Mean \pm SD & 48 & \pm 16 & 56 & \pm 16 & $<.001$ & 58 & \pm 15 & 57 & \pm 14 & .23 & 52 & \pm 14 & 53 & \pm 14 & .135 \\
\hline Median (IQR) & 47 & $35-61$ & 59 & $48-67$ & & 60 & $48-71$ & 59 & $44-67$ & & 29 & $27-32$ & 27 & $25-29$ & \\
\hline Age categories & & & & & $<.001$ & & & & & .014 & & & & & .343 \\
\hline 18-30 Years & 203 & $17 \%$ & 13 & $10 \%$ & & 58 & $6 \%$ & 0 & $0 \%$ & & 165 & $8 \%$ & 22 & $7 \%$ & \\
\hline 31-50 Years & 456 & $37 \%$ & 22 & $18 \%$ & & 218 & $22 \%$ & 27 & $32 \%$ & & 735 & $34 \%$ & 89 & $29 \%$ & \\
\hline 51-65 Years & 337 & $27 \%$ & 49 & $39 \%$ & & 280 & $29 \%$ & 29 & $34 \%$ & & 785 & $37 \%$ & 124 & $41 \%$ & \\
\hline Older than $65 \mathrm{y}$ & 230 & $19 \%$ & 41 & $33 \%$ & & 426 & $43 \%$ & 29 & $34 \%$ & & 463 & $22 \%$ & 67 & $22 \%$ & \\
\hline \multicolumn{16}{|l|}{ Sex } \\
\hline Total* & 1224 & $100 \%$ & 124 & $98 \%$ & & 980 & $100 \%$ & 84 & $98 \%$ & & 2153 & $99 \%$ & 302 & $99 \%$ & \\
\hline Female & 214 & $17 \%$ & 31 & $25 \%$ & .043 & 367 & $37 \%$ & 24 & $29 \%$ & .105 & 374 & $17 \%$ & 40 & $13 \%$ & .073 \\
\hline \multicolumn{16}{|l|}{ Dissection } \\
\hline Total $^{*}$ & 1218 & $99 \%$ & 125 & $99 \%$ & & 975 & $99 \%$ & 84 & $98 \%$ & & 2155 & $99 \%$ & 199 & $65 \% \dagger$ & \\
\hline Yes & 3 & $0.2 \%$ & 1 & $0.8 \%$ & .502 & 98 & $10 \%$ & 5 & $6.0 \%$ & .224 & 153 & $7.1 \%$ & 11 & $5.5 \%$ & \\
\hline \multicolumn{16}{|l|}{ Endocarditis } \\
\hline Total $^{*}$ & 1223 & $100 \%$ & 125 & $99 \%$ & & 971 & $99 \%$ & 83 & $97 \%$ & & 2155 & $99 \%$ & 199 & $65 \% \dagger$ & \\
\hline Yes & 34 & $2.8 \%$ & 19 & $15 \%$ & $<.001$ & 1 & $0.1 \%$ & 2 & $2.4 \%$ & .017 & 7 & $0.3 \%$ & 16 & $8.0 \%$ & \\
\hline AV leaflets & & & & & $<.001$ & & & & & $<.001$ & & & & & $<.001$ \\
\hline Total* & 1228 & $100 \%$ & 125 & $99 \%$ & & 977 & $99 \%$ & 82 & $95 \%$ & & 2163 & $100 \%$ & 296 & $97 \%$ & \\
\hline Tricuspid & 547 & $45 \%$ & 88 & $70 \%$ & & 534 & $55 \%$ & 34 & $41 \%$ & & 1344 & $62 \%$ & 147 & $50 \%$ & \\
\hline Bicuspid & 579 & $47 \%$ & 32 & $26 \%$ & & 367 & $38 \%$ & 35 & $43 \%$ & & 779 & $36 \%$ & 120 & $41 \%$ & \\
\hline Unicuspid & 91 & $7.4 \%$ & 2 & $1.6 \%$ & & 75 & $7.7 \%$ & 13 & $16 \%$ & & 38 & $1.8 \%$ & 27 & $9.1 \%$ & \\
\hline Quadricuspid & 11 & $0.9 \%$ & 3 & $2.4 \%$ & & 1 & $0 \%$ & 0 & $0 \%$ & & 2 & $0 \%$ & 2 & $0.7 \%$ & \\
\hline \multicolumn{16}{|l|}{$\begin{array}{l}\text { Previous cardiac } \\
\text { surgery }\end{array}$} \\
\hline Total $^{*}$ & 1095 & $89 \% \ddagger$ & 124 & $98 \%$ & & 887 & $90 \%$ & 83 & $97 \%$ & & 1883 & $87 \% \ddagger$ & 194 & $64 \% \dagger$ & \\
\hline Yes & 85 & $7.8 \%$ & 18 & $14.5 \%$ & & 23 & $2.6 \%$ & 13 & $15.7 \%$ & & 117 & $6.2 \%$ & 20 & $10.3 \%$ & \\
\hline \multicolumn{16}{|l|}{ Preoperative LVEF } \\
\hline Total* & 1100 & $90 \%$ & 121 & $96 \%$ & & 858 & $87 \% \ddagger$ & 79 & $92 \%$ & & 1892 & $87 \% \ddagger$ & 291 & $95 \%$ & \\
\hline Good $(>50 \%)$ & 822 & $75 \%$ & 94 & $78 \%$ & & 725 & $84 \%$ & 69 & $87 \%$ & & 1545 & $82 \%$ & 242 & $83 \%$ & \\
\hline $\begin{array}{l}\text { Moderate } \\
\qquad(31 \%-50 \%)\end{array}$ & 254 & $23 \%$ & 25 & $21 \%$ & & 106 & $12 \%$ & 9 & $11 \%$ & & 307 & $16 \%$ & 39 & $13 \%$ & \\
\hline Poor $(21 \%-30 \%)$ & 21 & $1.9 \%$ & 2 & $1.7 \%$ & & 11 & $1.3 \%$ & 1 & $1.3 \%$ & & 20 & $1.1 \%$ & 10 & $3.4 \%$ & \\
\hline Very poor $(\leq 20 \%)$ & 3 & $0.3 \%$ & 0 & $0 \%$ & & 16 & $1.9 \%$ & 0 & $0 \%$ & & 20 & $1.1 \%$ & 0 & $0.0 \%$ & \\
\hline \multicolumn{16}{|l|}{ Preoperative AR } \\
\hline Total $^{*}$ & 1169 & $95 \%$ & 90 & $71 \% \dagger$ & & 880 & $89 \% \ddagger$ & 62 & $72 \% \dagger$ & & 1911 & $88 \% \ddagger$ & 277 & $91 \%$ & \\
\hline $\begin{array}{l}\text { Grade } 0 \text { (none } \\
\quad \text { or trivial) }\end{array}$ & 3 & $0 \%$ & 3 & $3.3 \%$ & & 44 & $5.0 \%$ & 4 & $6.5 \%$ & & 145 & $7.6 \%$ & 16 & $5.8 \%$ & \\
\hline Grade 1 (mild) & 60 & $5.1 \%$ & 4 & $4.4 \%$ & & 206 & $23 \%$ & 5 & $8.1 \%$ & & 306 & $16 \%$ & 31 & $11 \%$ & \\
\hline $\begin{array}{l}\text { Grade } 2 \text { (mild } \\
\text { to moderate) }\end{array}$ & 137 & $12 \%$ & 7 & $7.8 \%$ & & 258 & $29 \%$ & 16 & $26 \%$ & & 404 & $21 \%$ & 61 & $22 \%$ & \\
\hline $\begin{array}{l}\text { Grade } 3 \text { (moderate } \\
\text { to severe) }\end{array}$ & 662 & $57 \%$ & 52 & $58 \%$ & & 284 & $32 \%$ & 26 & $42 \%$ & & 767 & $40 \%$ & 98 & $35 \%$ & \\
\hline Grade 4 (severe) & 307 & $26 \%$ & 24 & $27 \%$ & & 88 & $10 \%$ & 11 & $18 \%$ & & 289 & $15 \%$ & 71 & $26 \%$ & \\
\hline COPD & & & & & & & & & & & & & & & \\
\hline Total* & 1105 & $90 \%$ & 124 & $98 \%$ & & 896 & $91 \%$ & 83 & $97 \%$ & & 1889 & $87 \% \ddagger$ & 197 & $65 \% \dagger$ & \\
\hline Yes & 29 & $2.6 \%$ & 8 & $6.5 \%$ & .027 & 62 & $6.9 \%$ & 4 & $4.8 \%$ & .465 & 71 & $3.8 \%$ & 5 & $2.5 \%$ & \\
\hline
\end{tabular}


TABLE 1. Continued

\begin{tabular}{|c|c|c|c|c|c|c|c|c|c|c|c|c|c|c|c|}
\hline & \multicolumn{5}{|c|}{ Isolated AV surgery } & \multicolumn{5}{|c|}{$\begin{array}{c}\text { Partial root and/or tubular } \\
\text { aorta replacement } \\
\text { with AV surgery }\end{array}$} & \multicolumn{5}{|c|}{$\begin{array}{c}\text { Root replacement } \\
\text { with AV surgery }\end{array}$} \\
\hline & \multicolumn{2}{|c|}{$\begin{array}{c}\text { Repair } \\
(\mathrm{n}=\mathbf{1 2 2 8}) \\
\end{array}$} & \multicolumn{2}{|c|}{$\begin{array}{c}\text { Replacement } \\
(\mathrm{n}=126)\end{array}$} & \multirow{2}{*}{$\begin{array}{c}P \\
\text { value }\end{array}$} & \multicolumn{2}{|c|}{$\begin{array}{c}\text { Repair } \\
(\mathbf{n}=984)\end{array}$} & \multicolumn{2}{|c|}{$\begin{array}{l}\text { Replacement } \\
(\mathrm{n}=\mathbf{8 6})\end{array}$} & \multirow{2}{*}{$\begin{array}{c}P \\
\text { value }\end{array}$} & \multicolumn{2}{|c|}{$\begin{array}{c}\text { Repair } \\
(n=2168)\end{array}$} & \multicolumn{2}{|c|}{$\begin{array}{c}\text { Replacement } \\
(\mathbf{n}=\mathbf{3 0 5})\end{array}$} & \multirow{2}{*}{$\begin{array}{c}P \\
\text { value }\end{array}$} \\
\hline & $\mathbf{n}$ & $\%$ & $\mathbf{n}$ & $\%$ & & n & $\%$ & n & $\%$ & & $\bar{n}$ & $\%$ & $\bar{n}$ & $\%$ & \\
\hline \multicolumn{16}{|l|}{ IDDM } \\
\hline Total* & 1102 & $90 \%$ & 123 & $98 \%$ & & 893 & $91 \%$ & 82 & $95 \%$ & & 1889 & $87 \% \ddagger$ & 301 & $99 \%$ & \\
\hline Yes & 16 & $1.5 \%$ & 8 & $6.5 \%$ & .002 & 14 & $1.6 \%$ & 5 & $6.1 \%$ & .017 & 38 & $2.0 \%$ & 6 & $2.0 \%$ & \\
\hline \multicolumn{16}{|l|}{$\begin{array}{l}\text { Cross-clamp time, } \\
\text { minutes }\end{array}$} \\
\hline Total* & 1213 & $99 \%$ & 123 & $98 \%$ & & 969 & $98 \%$ & 84 & $98 \%$ & & 2136 & $99 \%$ & 297 & $97 \%$ & \\
\hline Median (IQR) & 53 & $32-85$ & 74 & $57-105$ & $<.001$ & 60 & $44-90$ & 114 & $88-163$ & $<.001$ & 111 & $76-148$ & 110 & $88-152$ & .063 \\
\hline \multicolumn{16}{|c|}{ Additional procedures } \\
\hline Total $*$ & 1227 & $100 \%$ & 125 & $99 \%$ & & 981 & $100 \%$ & 85 & $99 \%$ & & 2164 & $100 \%$ & 202 & $66 \% \dagger$ & \\
\hline Yes & 413 & $34 \%$ & 49 & $39 \%$ & .213 & 648 & $66 \%$ & 41 & $48 \%$ & .001 & 1248 & $58 \%$ & 82 & $41 \%$ & \\
\hline CABG & 118 & $9.6 \%$ & 14 & $11 \%$ & .721 & 110 & $11 \%$ & 9 & $11 \%$ & .005 & 200 & $9.2 \%$ & 18 & $8.9 \%$ & \\
\hline Aorta & 3 & $0.2 \%$ & 0 & $0.0 \%$ & .783 & 316 & $32 \%$ & 20 & $24 \%$ & .004 & 418 & $19 \%$ & 20 & $9.9 \%$ & \\
\hline Mitral valve & 200 & $16 \%$ & 13 & $10 \%$ & .023 & 38 & $3.9 \%$ & 5 & $5.9 \%$ & .002 & 82 & $3.8 \%$ & 8 & $4.0 \%$ & \\
\hline Maze & 88 & $7.2 \%$ & 5 & $4.0 \%$ & .349 & 49 & $5.0 \%$ & 3 & $3.5 \%$ & .005 & 89 & $4.1 \%$ & 7 & $3.5 \%$ & \\
\hline Other & 257 & $21 \%$ & 27 & $22 \%$ & .486 & 546 & $56 \%$ & 17 & $20 \%$ & $<.001$ & 1033 & $48 \%$ & 50 & $25 \%$ & \\
\hline
\end{tabular}

$A V$, Aortic valve; $S D$, standard deviation; $I Q R$, interquartile range; $L V E F$, left ventricular ejection fraction; $A R$, aortic regurgitation; $C O P D$, chronic obstructive pulmonary disease; $I D D M$, insulin-dependent diabetes mellitus; $C A B G$, coronary arterial bypass grafting. *The complete cases for that particular variable. $\nmid$ More than $20 \%$ missing values. $\ddagger$ Ten percent to $20 \%$ missing values. When $>10 \%$ was missing in one group no statistical tests were performed.

in cases of multiple large fenestrations ${ }^{22}$ ? The AVIATOR registry could contribute to these debates.

\section{STRENGTHS AND WEAKNESSES \\ Data Completeness}

The AVIATOR registry is a voluntary registry and leans on the effort participants are willing to put in. Data completeness can be at risk especially for: (1) registration of detailed valve cusps characteristics; (2) longitudinal event, survival, and echo follow-up; (3) selection of complete cohort in 1 center; (4) enrollment of consecutive cases; and (5) uniform reporting. (1) The registration must contain valve details to be of an additive value to national registries. These details comprise, for example, a description of the phenotype of each individual cusp assessed intraoperatively. The effective and geometric height can be registered as well. To make prospective data collection possible this information needs to be adapted in the local data collection logistics, for example as standard items in the operative notes for patients with AR. (2) One of the main outcome measures is the recurrence of AR over time. After discharge from the hospital, the care for the patient is frequently transferred to the cardiologist. When the cardiologist is not situated in the same hospital, it is likely that these patients get out of sight. It is important that echo results of all patients must be requested at a regular base (thus also from regional hospitals) to make longitudinal follow-up possible. The same holds for major events and survival. Follow-up completeness could be one of the validation criteria before selecting center data in research projects and publications. (3) The AVIATOR project is a longitudinal observational cohort study, meaning it attempts to follow all patients with AR or dystrophic aorta in time and to describe the patient characteristics, therapeutic interventions performed, and events down the track, whether they will be operated on or not, and whether they will undergo AV repair or replacement. It will take more effort to select the patients with AR who receive AV replacement. To gain more solid evidence for future guidelines, this patient group is vital. When the latter group is under-represented in the AVIATOR registry, it could easily be overcome by establishing partnerships in scientific projects with registries that complement the replaced valves. (4) By signing the participation agreement one confirms to enroll consecutive patients in that particular center. Only sending in the successful cases will lead to biased estimates of outcome and this will disadvantage future patients. The AVIATOR project objective is not to benchmark individual centers, but to improve patient care and future guidelines. In online reports it will be possible to see a center's own results against the complete cohort, as a tool to assess the center's position and to offer tools for improvement. Center-identifying data will be kept confidentially and will only be used for data validation purposes. (5) One of the main objectives of the AVIATOR initiative is to enhance uniform reporting but this is challenging. Take for example the echo parameters: are these measurements done the same in each institution? Probably not, and interinstitutional 
Partial root and/or

tubular aorta replacement with AV surgery

\begin{tabular}{|c|c|c|c|c|c|c|c|c|c|c|c|c|}
\hline & \multicolumn{4}{|c|}{ Isolated AV surgery } & \multicolumn{4}{|c|}{ with AV surgery } & \multicolumn{4}{|c|}{ with AV surgery } \\
\hline & \multicolumn{2}{|c|}{$\begin{array}{c}\text { Repair } \\
(n=1228)\end{array}$} & \multicolumn{2}{|c|}{$\begin{array}{l}\text { Replacement } \\
(\mathrm{n}=126)\end{array}$} & \multicolumn{2}{|c|}{$\begin{array}{c}\text { Repair } \\
(n=984)\end{array}$} & \multicolumn{2}{|c|}{$\begin{array}{l}\text { Replacement } \\
\quad(n=86)\end{array}$} & \multicolumn{2}{|c|}{$\begin{array}{c}\text { Repair } \\
(n=2168)\end{array}$} & \multicolumn{2}{|c|}{$\begin{array}{l}\text { Replacement } \\
(\mathbf{n}=\mathbf{3 0 5})\end{array}$} \\
\hline & $\begin{array}{c}\text { n or } \\
\text { median }\end{array}$ & $\begin{array}{l}\% \text { or } \\
\text { IQR }\end{array}$ & $\begin{array}{c}\text { n or } \\
\text { median }\end{array}$ & $\begin{array}{l}\% \text { or } \\
\text { IQR }\end{array}$ & $\begin{array}{c}\text { n or } \\
\text { median }\end{array}$ & $\begin{array}{l}\% \text { or } \\
\text { IQR }\end{array}$ & $\begin{array}{c}\text { n or } \\
\text { median }\end{array}$ & $\begin{array}{l}\% \text { or } \\
\text { IQR }\end{array}$ & $\begin{array}{c}\text { n or } \\
\text { median }\end{array}$ & $\begin{array}{l}\% \text { or } \\
\text { IQR }\end{array}$ & $\begin{array}{c}\text { n or } \\
\text { median }\end{array}$ & $\begin{array}{l}\% \text { or } \\
\text { IQR }\end{array}$ \\
\hline \multicolumn{13}{|l|}{$\begin{array}{c}\text { Postoperative aortic } \\
\text { regurgitation }\end{array}$} \\
\hline Total* & 971 & $79 \dagger$ & 100 & $79 \dagger$ & 754 & $77 \dagger$ & 59 & $69 \dagger$ & 1612 & $74 \dagger$ & 236 & $77 \dagger$ \\
\hline Grade 0 (none or trivial) & 410 & 42 & 72 & 72 & 394 & 52 & 55 & 93 & 1070 & 66 & 204 & 86 \\
\hline Grade 1 (mild) & 441 & 45 & 27 & 27 & 313 & 42 & 4 & 7 & 493 & 31 & 31 & 13 \\
\hline Grade 2 (mild to moderate) & 105 & 11 & 0 & 0 & 45 & 6 & 0 & 0 & 44 & 3 & 1 & 0 \\
\hline $\begin{array}{l}\text { Grade } 3 \text { (moderate to } \\
\text { severe) }\end{array}$ & 13 & 1.3 & 1 & 1.0 & 2 & 0.3 & 0 & 0 & 5 & 0.3 & 0 & 0 \\
\hline Grade 4 (severe) & 2 & 0.2 & 0 & 0 & 0 & 0 & 0 & 0 & 0 & 0 & 0 & 0 \\
\hline \multicolumn{13}{|l|}{ AV-related reintervention } \\
\hline Total* & 1212 & 99 & 102 & $81 \ddagger$ & 953 & 97 & 75 & $87 \dagger$ & 2130 & 98 & 289 & 95 \\
\hline Yes & 47 & 3.9 & 0 & 0 & 14 & 1.5 & 0 & 0 & 38 & 1.8 & 1 & 0 \\
\hline $\begin{array}{c}\text { Structural valve } \\
\text { dysfunction }\end{array}$ & 16 & 1.3 & 0 & 0 & 3 & 0.3 & 0 & 0 & 8 & 0.4 & 1 & 0 \\
\hline $\begin{array}{l}\text { Nonstructural valve } \\
\text { dysfunction }\end{array}$ & 0 & 0 & 0 & 0 & 0 & 0 & 0 & 0 & 1 & 0 & 0 & 0 \\
\hline $\begin{array}{c}\text { Unknown valve } \\
\text { dysfunction }\end{array}$ & 30 & 2.5 & 0 & 0 & 11 & 1.2 & 0 & 0 & 29 & 1.4 & 0 & 0 \\
\hline $\begin{array}{l}\text { Interval between both } \\
\text { procedures, } d\end{array}$ & 6 & $1-28$ & - & - & 6 & $0-8$ & - & - & 9 & $0-14$ & 8 & $8-8$ \\
\hline
\end{tabular}

Root replacement with AV surgery

Reoperation

(non-AV-related)

\begin{tabular}{|c|c|c|c|c|c|c|c|c|c|c|c|c|}
\hline Total* & 1213 & 99 & 100 & $79 \dagger$ & 952 & 97 & 74 & $86_{+}^{\dagger}$ & 2131 & 98 & 290 & 95 \\
\hline Yes & 26 & 2.1 & 5 & 5.0 & 40 & 4.2 & 5 & 6.8 & 118 & 5.5 & 23 & 7.9 \\
\hline \multicolumn{13}{|l|}{$\begin{array}{l}\text { Vascular thromboembolic } \\
\text { event }\end{array}$} \\
\hline Total* & 441 & $36 \dagger$ & 101 & $80_{7}^{\dagger}$ & 444 & $45^{\dagger}$ & 75 & $87 \dagger$ & 1184 & $55 \dagger$ & 285 & 93 \\
\hline Stroke & 1 & 0.2 & 0 & 0 & 8 & 1.8 & 0 & 0 & 15 & 1.3 & 3 & 1.0 \\
\hline TIA & 1 & 0.2 & 0 & 0 & 4 & 0.9 & 0 & 0 & 3 & 0.3 & 1 & 0.3 \\
\hline Peripheral embolism & 2 & 0.5 & 0 & 0 & 1 & 0 & 0 & 0 & 6 & 0.5 & 1 & 0.3 \\
\hline \multicolumn{13}{|l|}{ Pacemaker implantation } \\
\hline Total* & 1207 & 98 & 100 & $79 \dagger$ & 943 & 96 & 75 & $87 \ddagger$ & 2116 & 98 & 204 & $67 \dagger$ \\
\hline Yes & 9 & 0.7 & 2 & 2.0 & 9 & 1.0 & 4 & 5.3 & 27 & 1.3 & 9 & 4.4 \\
\hline \multicolumn{13}{|l|}{ Other complication } \\
\hline Total* & 1210 & 99 & 99 & $79 \dagger$ & 947 & 96 & 75 & 87 & 2119 & 98 & 259 & $85 \ddagger$ \\
\hline Yes & 218 & 18 & 25 & 25 & 252 & 27 & 25 & 33 & & 0.0 & & 0.0 \\
\hline \multicolumn{13}{|l|}{ Status at discharge } \\
\hline Total* & 1217 & 99 & 103 & $82 \ddagger$ & 964 & 98 & 77 & 90 & 2132 & 98 & 297 & 97 \\
\hline Death & 6 & 0.5 & 1 & 1.0 & 16 & 1.7 & 2 & 2.6 & 25 & 1.2 & 6 & 2.0 \\
\hline \multicolumn{13}{|l|}{$\mathrm{LOS}, \mathrm{d}$} \\
\hline Total* & 436 & $36 \dagger$ & 111 & 88 & 328 & $33 \dagger$ & 77 & 90 & 1106 & $51 \dagger$ & 279 & 91 \\
\hline LOS & 8 & $7-10$ & 8 & $7-16$ & 8 & $7-11$ & 8 & $7-11$ & 8 & $6-11$ & 9 & $7-13$ \\
\hline
\end{tabular}

Non-AV-related reoperation regardless of the reason, included bleeding/tamponade, mediastinitis, cardiac (other than AV-related) and noncardiac reoperation. $A V$, Aortic valve; $I Q R$, interquartile range; $T I A$, transient ischemic attack; $L O S$, length of stay. *The complete cases for that particular variable. $†$ More than $20 \%$ missing values. $\ddagger$ Ten percent to $20 \%$ missing values. When $>20 \%$ was missing in one group no statistical tests were performed. 
variation is likely. Here lays a potential role for standardized analysis by core echo labs in the future.

\section{Data Validation}

Data quality is a major concern for voluntary databases. Even when there is no intention to game, data entry could lead to data inaccuracy just by human errors. Data validation should occur at different levels. The online application system contains some simple internal validation rules, like the occurrences of dates in a logical order and build-in ranges for parametric values. Missing values and data completeness should be part of the feedback reports. These reports will be transparent to everyone, enabling social pressure to be complete among participants. The AVIATOR project is planning to define an audit strategy. Data auditing between centers within 1 country or random selection of $5 \%-10 \%$ of data in combination with site visits could be an option. This will allow assessment of data accuracy. To assess if the complete cohort (all consecutive patients) was entered and whether survival data are accurate is more difficult. Linkage to national cardiac surgery registries, including national death registries could be an option. Nevertheless, the feasibility could vary between countries. Because data auditing is costly, it needs to be incorporated in future grants for the AVIATOR project.

\section{Natural History of AR and International Coverage}

One of the main strengths of the AVIATOR initiative is the collaboration of surgeons and cardiologists to span the whole trajectory of AR and ascending aorta aneurysm patients from diagnosis, to medical or surgical intervention and beyond. This will improve the fundamental understanding of the natural history, etiology, and mechanisms of AR. Moreover, it will allow to investigate, evaluate, and improve the treatment strategies and ultimately, to provide a solid evidence base for future guidelines. The AVIATOR initiative has brought together many experts in the field of dystrophic AR from all over the world. The registry is open to everyone and the international coverage makes it a unique initiative.

\section{CONCLUSIONS}

The international prospective AVIATOR registry already includes 4836 patients. However, because the road toward a perfect representative sample of global clinical practice is a bumpy one, the challenges for the upcoming years are evident. There is a need to focus on data completeness and data quality of the current centers. To avoid cherry-picking, enrollment of consecutive patients need to be monitored, including the replaced valves in all participating centers, and adequate follow-up completeness needs to be established for meaningful analyses. By combining surgical experience from multiple centers, and applying uniform definitions of echo and outcome parameters, it should become possible to provide a solid evidence base to clarify and standardize the place of repair versus replacement in $\mathrm{AV}$ surgery and to provide an evidence base for tailored treatment in the individual patient.

\section{Conflict of Interest Statement}

Emmanuel Lansac has Consultant Agreements with the company CORONEO, Inc (www.coroneo.com), in connection with the development of an aortic ring bearing the trade name, "Extra-Aortic." All other authors have nothing to disclose with regard to commercial support.

We thank all institutional and individual members of the AVIATOR (Appendix 1) for their continuous support and contributions.

\section{References}

1. Bonow RO, Lakatos E, Maron BJ, Epstein SE. Serial long-term assessment of the natural history of asymptomatic patients with chronic aortic regurgitation and normal left ventricular systolic function. Circulation. 1991;84:1625-35.

2. Singh JP, Evans JC, Levy D, Larson MG, Freed LA, Fuller DL, et al. Prevalence and clinical determinants of mitral, tricuspid, and aortic regurgitation (the Framingham heart study). Am J Cardiol. 1999;83:897-902.

3. Bekeredjian R, Grayburn PA. Valvular heart disease: aortic regurgitation. Circulation. 2005;112:125-34.

4. Iung B. A prospective survey of patients with valvular heart disease in Europe: the Euro heart survey on valvular heart disease. Eur Heart J. 2003;24:1231-43.

5. Sarsam MA, Yacoub M. Remodeling of the aortic valve anulus. J Thorac Cardiovasc Surg. 1993;105:435-8.

6. David TE, Feindel CM. An aortic valve-sparing operation for patients with aortic incompetence and aneurysm of the ascending aorta. J Thorac Cardiovasc Surg. 1992;103:617-21; discussion: 622.

7. Lansac E, Di Centa I, Sleilaty G, Crozat EA, Bouchot O, Hacini R, et al. An aortic ring: from physiologic reconstruction of the root to a standardized approach for aortic valve repair. J Thorac Cardiovasc Surg. 2010;140:S28-35; discussion: S45-51.

8. Boodhwani M, de Kerchove L, Glineur D, Poncelet A, Rubay J, Astarci P, et al. Repair-oriented classification of aortic insufficiency: impact on surgical techniques and clinical outcomes. J Thorac Cardiovasc Surg. 2009;137:286-94.

9. El Khoury G, Glineur D, Rubay J, Verhelst R, d'Acoz Y, Poncelet A, et al. Functional classification of aortic root/valve abnormalities and their correlation with etiologies and surgical procedures. Curr Opin Cardiol. 2005;20:115-21.

10. Lansac E, Di Centa I, Raoux F, Al Attar N, Acar C, Joudinaud T, et al. A lesional classification to standardize surgical management of aortic insufficiency towards valve repair. Eur J Cardiothorac Surg. 2008;33:872-8; discussion: 878-80.

11. Schafers HJ, Bierbach B, Aicher D. A new approach to the assessment of aortic cusp geometry. J Thorac Cardiovasc Surg. 2006;132:436-8.

12. Stamou SC, Williams ML, Gunn TM, Hagberg RC, Lobdell KW, Kouchoukos NT. Aortic root surgery in the United States: a report from the Society of Thoracic Surgeons database. J Thorac Cardiovasc Surg. 2015;149: 116-22.e4.

13. Gaudino M, Lau C, Munjal M, Avgerinos D, Girardi LN. Contemporary outcomes of surgery for aortic root aneurysms: a propensity-matched comparison of valve-sparing and composite valve graft replacement. J Thorac Cardiovasc Surg. 2015;150:1120-9.e1.

14. Caceres M, Ma Y, Rankin JS, Saha-Chaudhuri P, Englum BR, Gammie JS, et al. Mortality characteristics of aortic root surgery in North America. Eur $J$ Cardiothorac Surg. 2014;46:887-93.

15. Arabkhani B, Mookhoek A, Di Centa I, Lansac E, Bekkers JA, De Lind Van Wijngaarden $\mathrm{R}$, et al. Reported outcome after valve-sparing aortic root replacement for aortic root aneurysm: a systematic review and meta-analysis. Ann Thorac Surg. 2015;100:1126-31.

16. Mookhoek A, Korteland NM, Arabkhani B, Di Centa I, Lansac E, Bekkers JA, et al. Bentall procedure: a systematic review and meta-analysis. Ann Thorac Surg. 2016;101:1684-9.

17. Vahanian A, Alfieri O, Andreotti F, Antunes MJ, Baron-Esquivias G, Baumgartner $\mathrm{H}$, et al. Guidelines on the management of valvular heart disease (version 2012): the joint task force on the management of valvular heart disease 
of the European Society of Cardiology (ESC) and the European Association for Cardio-Thoracic Surgery (EACTS). Eur J Cardiothorac Surg. 2012;42:S1-44.

18. Nishimura RA, Carabello BA, Faxon DP, Freed MD, Lytle BW, O'Gara PT, et al. ACC/AHA 2008 guideline update on valvular heart disease: focused update on infective endocarditis: a report of the American College of Cardiology/American Heart Association task force on practice guidelines endorsed by the Society of Cardiovascular Anesthesiologists, Society for Cardiovascular Angiography and interventions, and Society of Thoracic surgeons. J Am Coll Cardiol. 2008;52: 676-85.

19. Akins CW, Miller DC, Turina MI, Kouchoukos NT, Blackstone EH, Grunkemeier GL, et al. Guidelines for reporting mortality and morbidity after cardiac valve interventions. Eur J Cardiothorac Surg. 2008;33:523-8.
20. Wu Y, Takkenberg JJ, Grunkemeier GL. Measuring follow-up completeness Ann Thorac Surg. 2008;85:1155-7.

21. Telemedicine Technologies. Available at: http://www.tentelemed.com/en/. Accessed November 27, 2018

22. Lansac E, de Kerchove L. Aortic valve repair techniques: state of the art. Eur J Cardiothorac Surg. 2018;53:1101-7.

Key Words: aortic valve regurgitation, ascending aortic aneurysm, valve surgery, outcome analysis, international registry, long-term echocardiographic follow-up

Readers who found these articles interesting may also like to read the following papers found in recent and future issues of our sister publications, Seminars in Thoracic and Cardiovascular Surgery and Operative Techniques in Thoracic and Cardiovascular Surgery!

\section{Adult: Aortic Valve}

EXPERT REVIEW: Postoperative Outcomes in SAVR/TAVR Patients with Cognitive Impairment: A Systematic Review. Richard D. Urman. Semin Thoracic Surg 2018: In press

ORIGINAL SUBMISSION: The Button Bentall Procedure. Nicholas T. Kouchoukos. Oper Tech Thorac Cardiovasc Surg 2018: In press

ORIGINAL SUBMISSION: Transprosthetic Cuff Leakage of a Bovine Pericardial Aortic Bioprosthesis. Taichi Sakaguchi. Semin Thoracic Surg 2019: In press

ORIGINAL MANUSCRIPT: Outcomes After Aortic Valve Replacement for Asymptomatic Severe Aortic Regurgitation and Normal Ejection Fraction. Kazuhiro Taniguchi. Semin Thoracic Surg 2019: In Press

ORIGINAL MANUSCRIPT: Outcomes After Aortic Valve Replacement for Asymptomatic Severe Aortic Regurgitation and Normal Ejection Fraction. Arudo Hiraoka. Semin Thoracic Surg 2018: In Press

ORIGINAL MANUSCRIPT: Impact of Prosthesis Size and Prosthesis-Patient Mismatch on Outcomes in Younger Female Patients Undergoing Aortic Valve Replacement. Tsuyoshi Kaneko. Semin Thoracic Surg 2019: In press

Commentary: The Mind Is Your Best Muscle: TAVR/SAVR Outcomes in Patients With Cognitive Impairment. Judson B. Williams,. Semin Thoracic Surg 2019: In press

ORIGINAL SUBMISSION: Comparison of survival after aortic valve replacement with Mitroflow or Perimount prostheses. Kristian Aasbjerg. Semin Thoracic Surg 2018: In press

Commentary: Not All Bioprosthetic Valves Are Created Equal. Christopher Malaisrie. Semin Thoracic Surg 2019: In press

ORIGINAL SUBMISSION: Sutureless Valve Replacement Through a Right Anterior Minithoracotomy in Elderly Patients With

Stenotic Bicuspid Aortic Valve. Mustafa Serkan Durdu. Semin Thoracic Surg 2018: In press

CASE REPORT: Severe Thoracic Aorta Stenosis After Endovascular Treatment of Blunt Thoracic Aortic Injury. Aurelien Hostalrich.

Semin Thoracic Surg 2019: In Press 


\section{APPENDIX 1. AORTIC VALVE REPAIR INTERNATIONAL REGISTRY (AVIATOR) SITES AND INVESTIGATORS \\ Austria}

Department of Cardiac Surgery, Landeskrankenhaus Salzburg, Salzburg: Christian Dinges, MD, Johannes Steindl, and Rosina Ziller.

\section{Belgium}

Department of Cardiovascular and Thoracic Surgery, Cliniques universitaires Saint-Luc, Bruxelles: Laurent De Kerchove, MD, PhD, Taoufik Benkacem, Corinne Coulon, Gebrine Elkhoury, MD, PhD, Fadoua Kaddouri, Jean-Louis Vanoverschelde, MD, PhD, Christophe de Meester, MS, and Agnès Pasquet $\mathrm{MD}, \mathrm{PhD}$; Department of Cardiac Surgery, Universitair Ziekenhuis Brussel, Brussels: Jan Nijs, MD, and Veerle Van Mosselvelde; Department of Medical Genetics, Universiteit Antwerpen, Edegem: Bart Loeys, MD, PhD; Department of Cardiovascular Diseases, University Hospitals Leuven, Leuven: Bart Meuris, MD, $\mathrm{PhD}$, Evi Schepmans, Klaartje Van den Bossche, and Peter Verbrugghe, MD; Department of Cardiovascular Surgery, Ziekenhuis Oost Limburg, Genk: Wenke Goossens, Herbert Gutermann, MD, and Matteo Pettinari, MD.

\section{Canada}

Department of Cardiac Surgery, Montreal Heart Institue, Montréal: Ismail El-Hamamsy, MD, PhD, Marien Lenoir, Pierre-Emmanuel Noly, and Michael Tousch; Department of Surgery, University of Manitoba, Winnipeg: Pallav Shah, MD; Division of Cardiac Surgery, University of Ottawa Heart Institute, Ottawa: Munir Boodhwani, MD, MMSc.

\section{Croatia}

Department of Cardiac and Transplant Surgery, University Hospital Dubrava, Zagreb: Igor Rudez, MD, $\mathrm{PhD}$, Davor Baric, MD, PhD, Daniel Unic, MD, PhD, Josip Varvodic, MD, and Savica Gjorgijevska, MD.

\section{Czech Republic}

Department of Cardiac Surgery, Charles University Hospital, Hradec Kralove: Jan Vojacek, MD, PhD, Pavel Zacek, $\mathrm{MD}, \mathrm{PhD}$, and Mikita Karalko, MD; Department of Cardiovascular Surgery, General University Hospital, Prague: Jaroslav Hlubocky, MD, Robert Novotny, and Andrey Slautin.

\section{Egypt}

Department of Cardiothoracic surgery, Dar Al Fouad Hospital, Cairo: Said Soliman, MD.

\section{France}

Department of Cardiac Surgery, Centre Hospitalier Universitaire Grenoble Alpes, La Tronche: Eric ArnaudCrozat, and Aude Boignard; Department of Cardiac
Surgery, CHRU Lille, Lille: Georges Fayad; Department of Cardiac Surgery, CHU le Bocage, Dijon: Olivier Bouchot, MD, PhD; Department of Cardiac Surgery, CHU Montpellier-Hôpital Arnaud de Villeneuve, Montpellier: Bernard Albat; Department of Cardiac Surgery, CHU Rennes-Hôpital Ponchailloux, Rennes: Alain Leguerrier; Department of Cardiac Surgery, CHU Rouen-Hôpital Charles Nicolle, Rouen: Fabien Doguet; Department of Cardiac Surgery, CHU Saint-Etienne, Saint-Priest en Jarez: Jean-François Fuzellier; Department of Cardiac Surgery, CHU Toulouse-Hôpital Rangueil, Toulouse: Yves Glock; Department of Cardiology, Claude Bichat-Claude Bernard Hospital, Paris: Guillaume Jondeau, MD, PhD; Department of Cardiac Surgery, Clinique Saint-Augustin, Bordeaux: Guy Fernandez; Department of Cardiac Surgery, Clinique Saint-Gatien, Tours: Didier Chatel; Department of Cardiology, Hôpital Bichat, Paris: David Messika Zeitoun, $\mathrm{MD}$, PhD; Department of Cardiac Surgery, Hôpital Européen Georges Pompidou, Paris: Jérôme Jouan; Department of Vascular Surgery, Hopital Foch, Suresnes: Isabelle Di Centa, MD; Department of Cardiac Surgery, Hôpital Louis Pradel, Bron: Jean-François Obadia; Department of Cardiac Surgery, Hôpital Pitié Salpétrière, Paris: Pascal Leprince; Department of Cardiac Surgery, Hôpital Saint-Joseph, Marseille: Rémi Houel; Department of Cardiac and Thoracic Surgery, Hopitaux Henri Mondor, Creteil: Eric Bergoend, MD; Department of Cardiac Surgery, Institut Arnaud Tzanck, Saint-Laurent du Var: Stéphane Lopez; Department of Cardiac Surgery, Institut Mutualiste Montsouris, Paris: Alain Berrebi, MD, Emmanuel Lansac, MD, PhD, Stéphanie Lejeune, JeanLuc Monin, MD, PhD, Sarah Pousset, Florence Tubach, MD, PhD, Leila Mankoubi, MD, Milean Noghin, MD, Christelle Diakov, MD, and Daniel Czytrom, MD.

\section{Germany}

Department of Thoracic and Cardiovascular Surgery, Saarland University Medical Center, Homburg: HansJoachim Schäfers, MD, PhD, and Frank Theisohn; Department of Cardiovascular surgery, Cardiovascular Center Bad Bevensen: Diana Aicher, MD, PhD; Department of Cardiac Surgery, Leipzig Heart Center, Leipzig: Michael Borger, MD, PhD.

\section{Great Britain}

Department of Cardiac Surgery, Bristol heart Institute, Bristol: Paolo Ferrero, and Serban Stoica, FRCS; Department of Cardiothoracic Surgery, New Cross Hospital, Wolverhampton: Maciej Matuszewski, MD, and Patrick Yiu; Department of Cardiac Surgery, St Bartholomew's Hospital, London: Mohamad Bashir, MD, PhD, MRCS.

\section{Italy}

Department of Cardiac Surgery, Azienda Ospedaliera Papardo, Messina: Fabrizio Ceresa, and Francesco Patane, 
MD; Department of Cardiac Surgery, European Hospital, Rome: Ruggero De Paulis, MD, and Ilaria Chirichilli, MD; Department of Cardiac Surgery, Regional Hospital "Ca Foncello," Treviso: Mauro Masat, MD; Department of Cardiovascular Surgery-Azienda Socio Sanitaria Territoriale Fatebenefratelli Sacco, Università degli studi di Milano, Milano: Carlo Antona, MD, Monica Contino, MD, Andrea Mangini, MD, Claudia Romagnoni, MD, and Rubina Rosa; Department of Cardiology, Academic Hospital S. Orsola-Malpighi, Bologna: Francesco Grigioni, $\mathrm{MD}, \mathrm{PhD}$.

\section{Japan}

Department of Cardiovascular Surgery, Kobe University, Kobe: Yutaka Okita, MD; Department of Cardiothoracic surgery, Sakakibara Heart Institute, Tokyo: Yutaka Okita, MD; Department of Cardiovascular Surgery, St. Marianna University, School of Medicine, Kawasaki: Takeshi Miyairi, MD; Department of Cardiovascular Surgery, The Cardiovascular Institute, Tokyo: Takashi Kunihara, MD.

\section{The Netherlands}

Department of Cardiothoracic Surgery, Academic Medical Center Amsterdam, Amsterdam: Frederiek de Heer, MSc, Arjen Gökalp, MD, Mandy Marsman, Dave Koolbergen, MD, PhD, and Jolanda Kluin, MD, PhD; Department of Cardiothoracic Surgery, Erasmus MC Rotterdam, Rotterdam: Jos Bekkers, MD, PhD, Liesbeth Duininck, and Johanna J.M. Takkenberg, MD, PhD; Department of Cardiothoracic Surgery, Leiden University Medical Center, Leiden: Bardia Arabkhani, MD, PhD, Thomas Van Brakel, MD, PhD, and Robert Klautz, MD, $\mathrm{PhD}$; Department of Cardiothoracic surgery, Medisch Spectrum Twente, Enschede: Gianclaudio Mecozzi, MD; Department of Cardiac and Thoracic Surgery, University Medical Center Groningen, Groningen: Ryan Accord, MD, and Gianclaudio Mecozzi, MD.

\section{Poland}

Department of Cardiac Surgery, Central University Hospital, Wrocław: Marek Jasinski, MD, PhD.

\section{Russia}

Department of Cardiac Surgery, The Federal Center for Cardiovascular Surgery, Chelyabinsk: Vladislav Aminov, and Mihail Svetkin.

\section{Slovakia}

Department of Cardiovascular Surgery, East Slovakian Institute for Cardiac and Vascular Diseases, Kosice: Adrian Kolesar, MD, PhD, František Sabol, MD, and Tomas Toporcer.

\section{Spain}

Department of Cardiovascular Surgery, Clinica Universidad de Navarra, Pamplona: Ignacio Bibiloni, and Gregorio Rábago, MD; Department of Cardiac Surgery, Complejo Hospitalario de Navarra, Pamplona: Virginia Alvarez-Asiain, Amaia Melero, and Rafael Sadaba, MD; Department of Cardiovascular Surgery, Hospital de Cruces, Bilbao: José Aramendi, MD, and Alejandro Crespo MD; Department of Cardiovascular Surgery, Hospital Universitario Virgen de la Victoria de Málaga, Málaga: Carlos Porras, MD; Department of Cardiology, Hospital General Universitari Vall d'Hebron, Barcelona: Arturo Evangelista Masip, MD.

\section{United States of America}

Department of Cardiovascular Surgery, Hospital of the University of Pennsylvania, Philadelphia, Pennsylvania: Joseph Bavaria, MD, PhD, Rita Milewski, MD, PhD, Patrick Moeller, and Isaac Wenger; Department of Cardiovascular Diseases, Mayo Clinic, Rochester, Minnesota: Maurice Enriquez-Sarano, MD; Administration Office, HVS, Beverly, Massachusetts: Stan Alger, Aurelie Alger, Shelagh Kelley, and Katie Leavitt. 


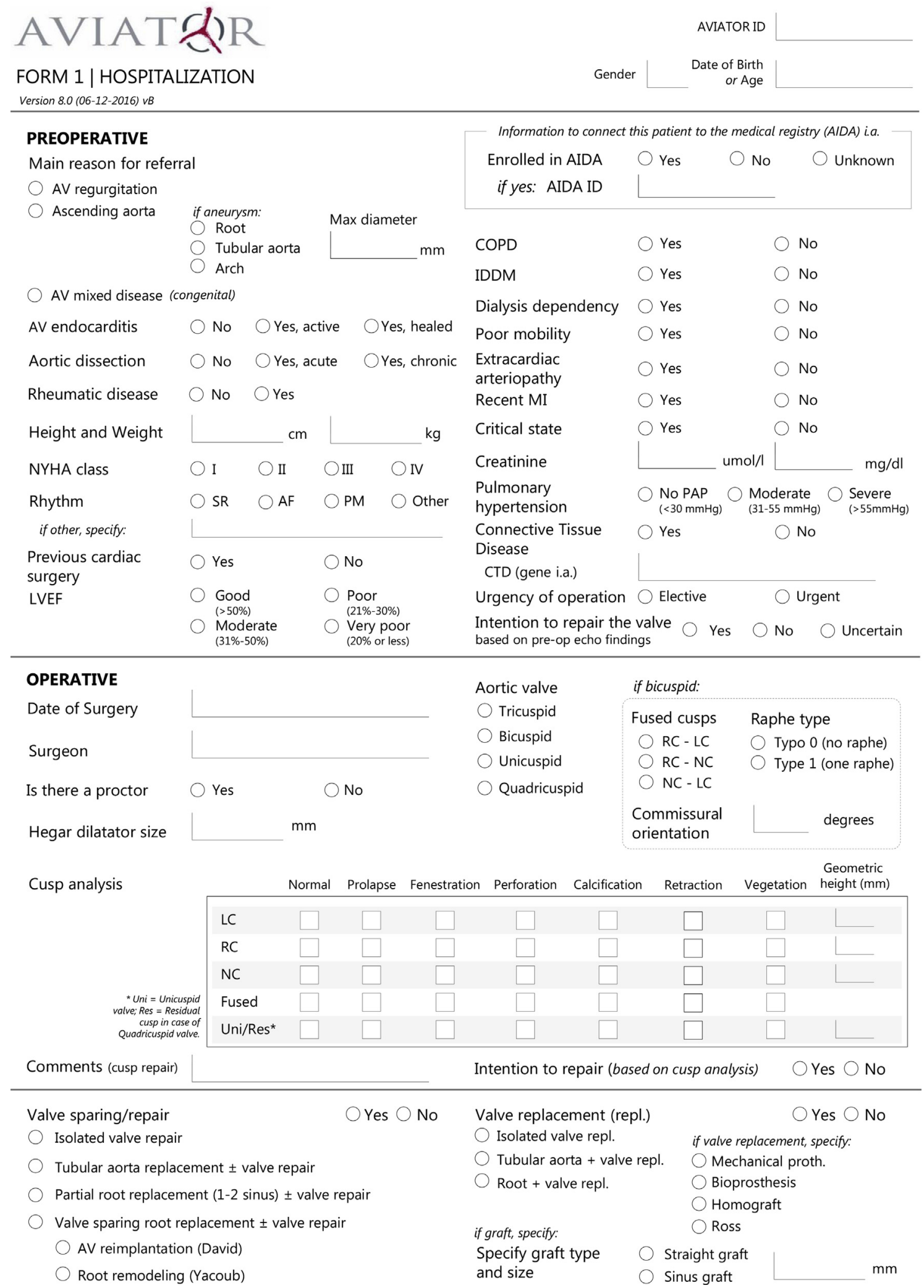

FIGURE E1. AVIATOR case report form. 


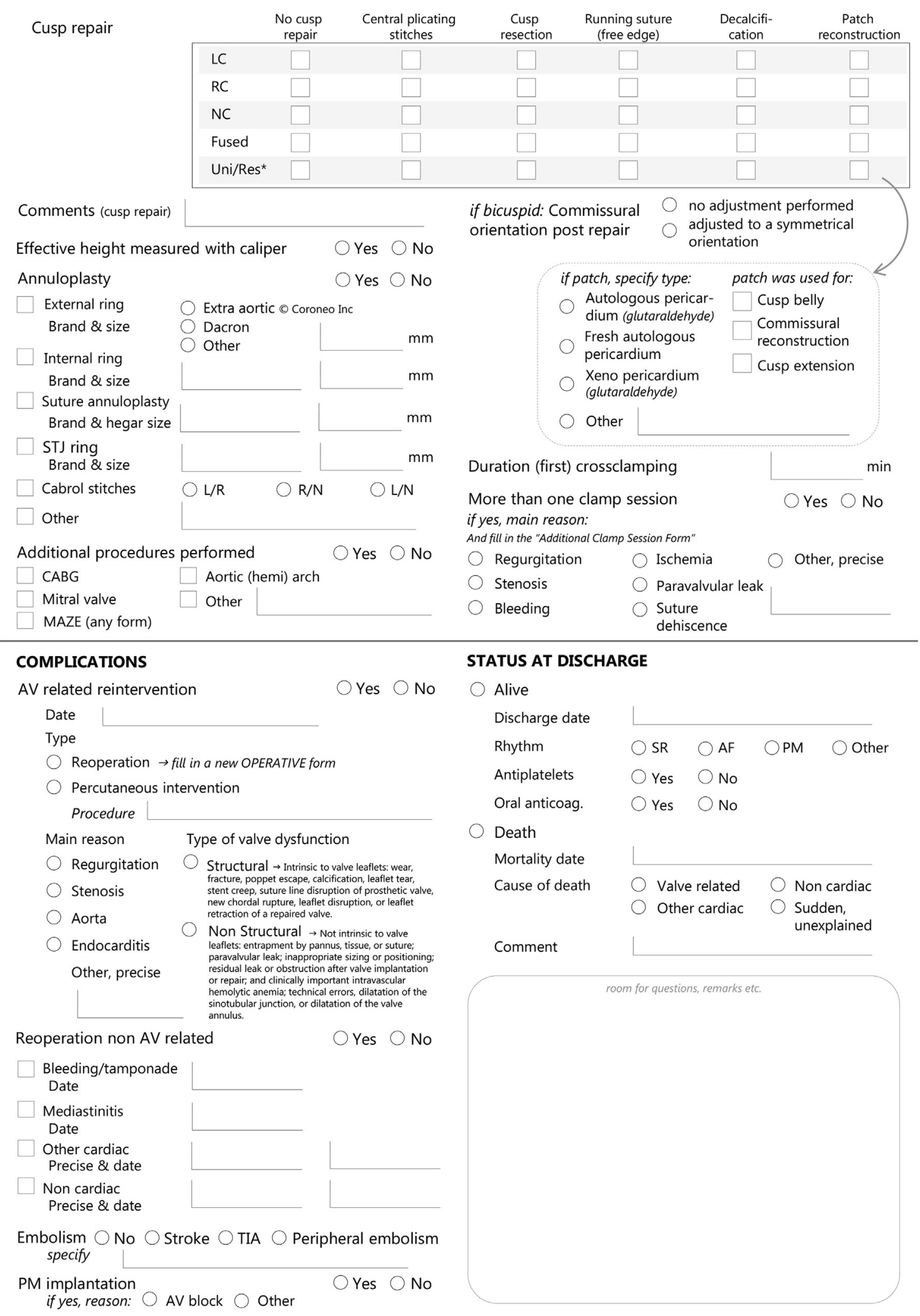

FIGURE E1. (continued). 


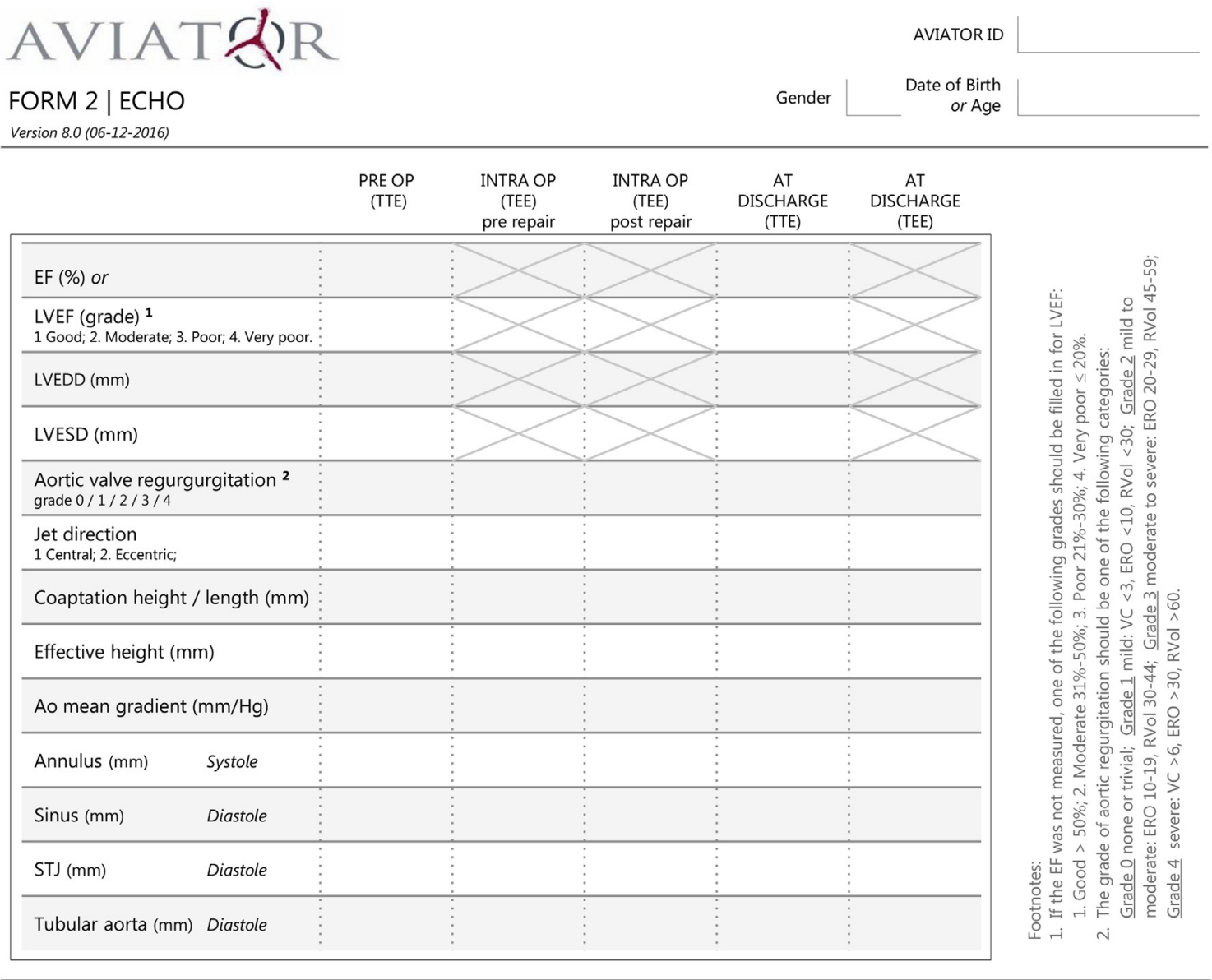

FIGURE E1. (continued). 


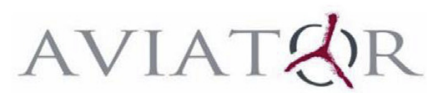

FORM 3 | ADDITIONAL CLAMP SESSION

Version 8.0 (06-12-2016)

$\Rightarrow$ Clamp session number

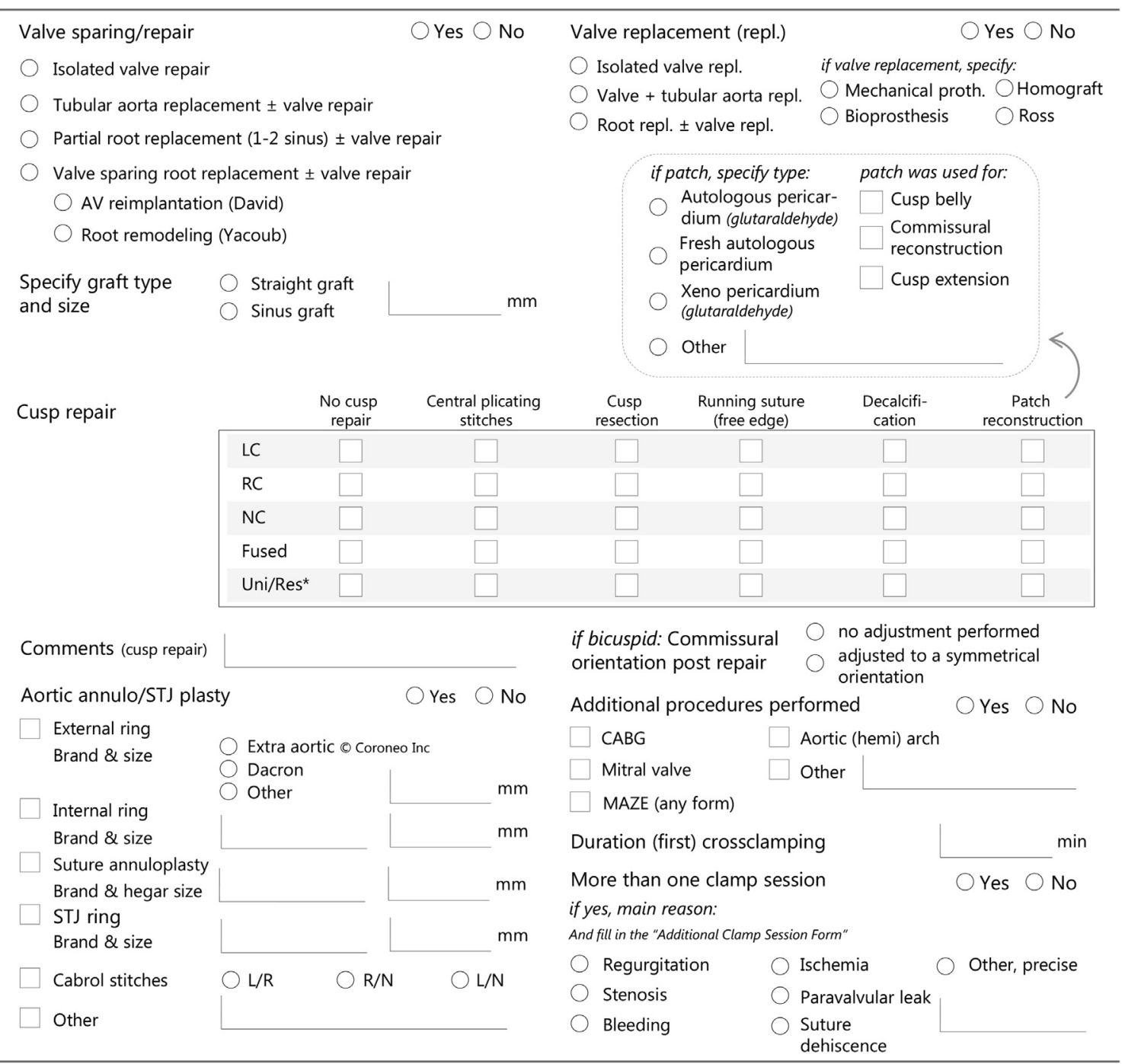

FIGURE E1. (continued). 


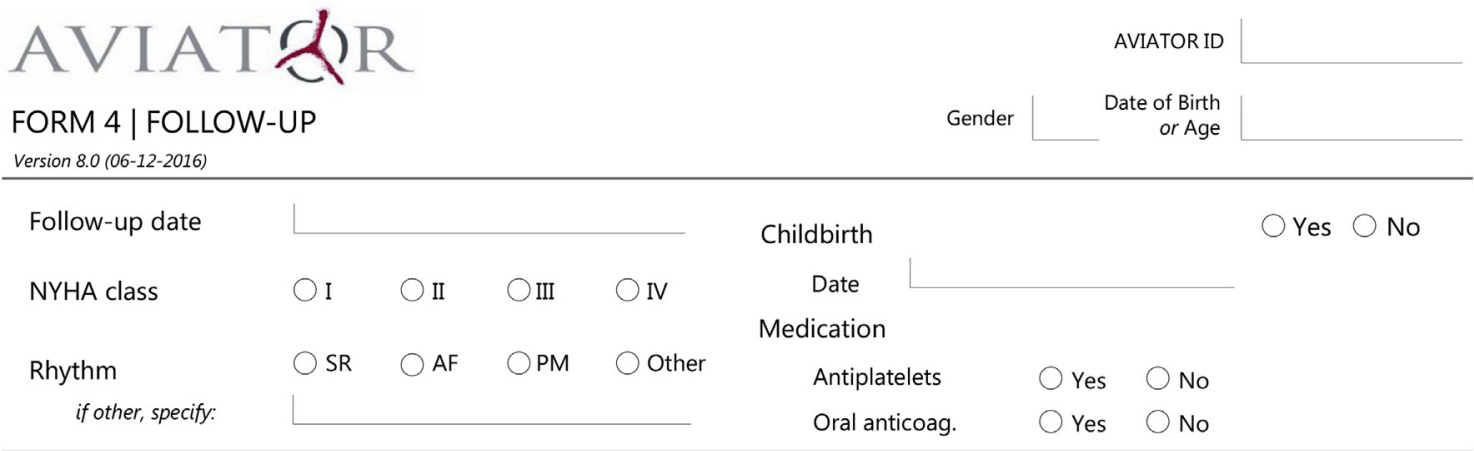

\section{COMPLCATIONS SINCE LAST FOLLOW-UP}

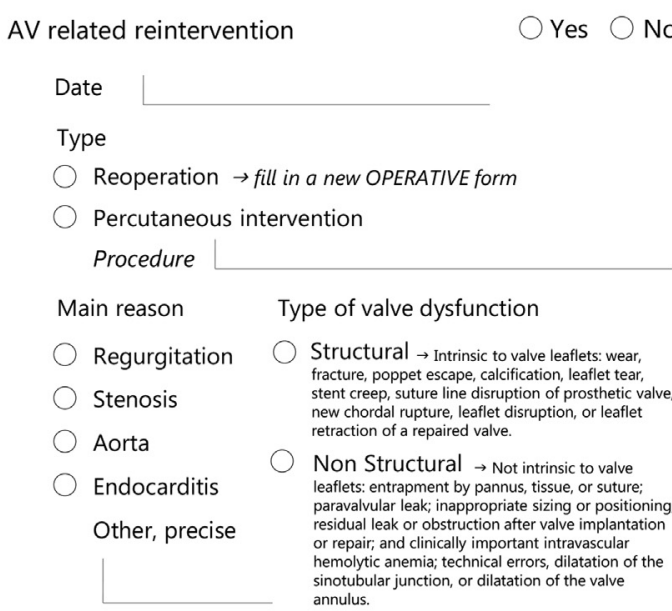

Other cardiac reoperation

$\bigcirc$ Yes $\bigcirc$ No

Date

Precise

Aorta complication (thoracic or abdominal) $\bigcirc$ Yes $\bigcirc$ No

Date

Precise

AV endocarditis (non operated) $\bigcirc$ Yes $\bigcirc$ No
Date

AV thrombosis (non operated) $\bigcirc$ Yes $\bigcirc \mathrm{No}$

Date

Embolism $\bigcirc$ No $\bigcirc$ Stroke $\bigcirc$ TIA $\bigcirc$ Peripheral embolism Specify

Date

Major bleeding

$\bigcirc$ Yes $\bigcirc$ No

Date

PM implantation

Yes $\bigcirc$ No

Date

Reason $\bigcirc$ AV block $\bigcirc$ Other

\section{SURVIVAL}

Death

$\bigcirc$ Yes $\bigcirc$ No

Date

Cause of Death

Valve related

Non cardiac

Other cardiac

Sudden, unexplained death

Comment

ECHO

TTE

TEE

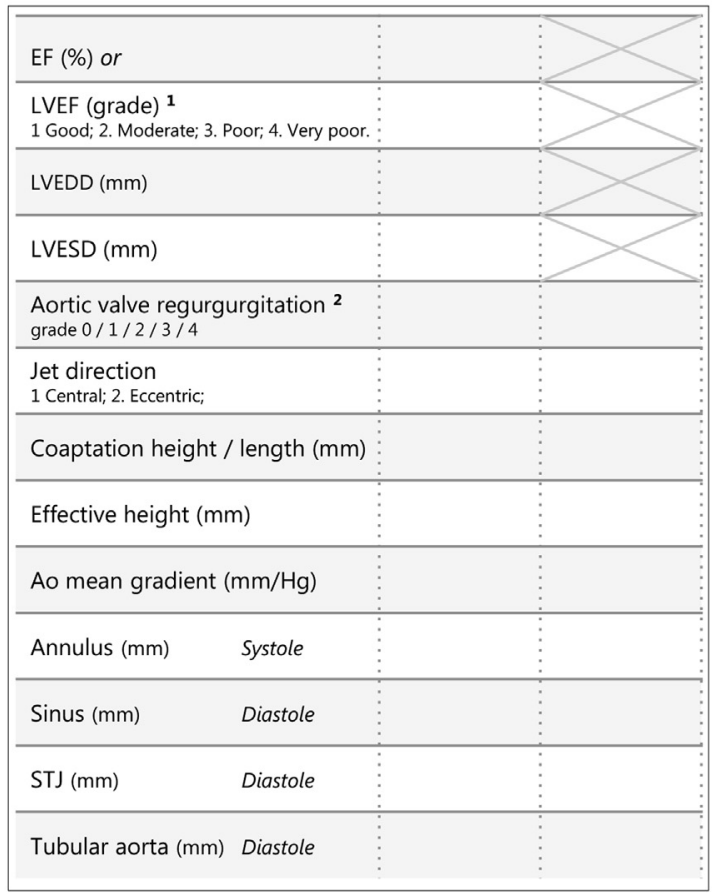

Footnotes:

1. If the EF was not measured, one of the following grades should be filled in for LVEF: 1 . Good > 50\%; 2. Moderate $31 \%-50 \%$; 3. Poor $21 \%$ $30 \%$; 4 . Very poor $\leq 20 \%$

2. The grade of aortic regurgitation should be one of the following categories: Grade 0 none or trivial; Grade 1 mild: VC $<3$, ERO $<10$ RVol <30; Grade 2 mild to moderate: ERO 10-19, RVol 30-44; Grade 3 moderate to severe: ERO 20-29, RVol 45-59; Grade 4 severe: VC $>6$, $\mathrm{ERO}>30, \mathrm{RVOl}>60$

FIGURE E1. (continued). 